\title{
AFTER THE PINNA NOBILIS L. MASS MORTALITY EVENT IN BOSNIA AND HERZEGOVINA - A PROPOSAL FOR REMEDIATION OF BIOFILTRATION SERVICES IN MARINE ECOSYSTEM
}

\author{
Mirza Čelebičićc ${ }^{*}$, Sabina Trakić1, Samir Đug ${ }^{2}$, Vedad Viteškić ${ }^{3}$
}

${ }^{1}$ Independent researcher, Sarajevo, Bosnia and Herzegovina

${ }^{2}$ Faculty of Science, Department of Biology, University of Sarajevo, Sarajevo, Bosnia and Herzegovina

${ }^{3}$ Faculty of Architecture,

University of Sarajevo,

Sarajevo, Bosnia and Herzegovina

*Corresponding author:

MA Mirza Čelebičić

Independent researcher

Adress: Stolačka 34

71000 Sarajevo,

Bosnia and Herzegovina

Phone: ++38762072157

ORCID: 0000-0003-3403-931X

E-mail: mirzacelebic@yahoo.com

Original Submission:

28 October 2021

Revised Submission:

22 November 2021

Accepted:

27 November 2021

\section{ABSTRACT}

The Mass Mortality Event (MME) of endemic bivalve Pinna nobilis occurred in the Mediterranean Sea and brought this species to the brink of extinction. So far, the etiology of the disease was determined to be multifactorial. Apart from a wide spectrum of pathogenic microorganisms as a key factor, the indirect role is played by climate changes, ie. the increase in sea water temperature, which rises sensitivity of $P$. nobilis toward pathogens. In terms of conservation measures, the IUCN guidelines are species- oriented and recommend in situ and ex situ conservation. In this study, we examined 10,920 $\mathrm{m}^{2}$ of seabed in the territorial waters of Bosnia and Herzegovina $(\mathrm{B} \& \mathrm{H})$ and confirmed the occurrence of MME with $100 \%$ mortality rate. Based on estimated Total Number of Individuals (TNI), the filtration capacity as an ecosystem service for the turbidity control in the Bay was assessed. Herein, we present a potential method for the assessment of ecosystem damages caused by the loss of fan shells and their biofiltration service. Our results showed that $58583 \pm 27879$ individuals were lost, which corresponds to the biomass of $11.47 \mathrm{t} \pm 6.41 \mathrm{t}$ ( \pm $55.87 \%$ ). Hourly filtration potential (PRF) of P. nobilis is $68722.11 \pm 38396.86( \pm 55.87 \%) 95 \% \mathrm{CI}$, meaning that all populations could filter the entire sea water in the Neum Bay $\left(0.2 \mathrm{~km}^{3}\right)$ in a period of 78-275 days. We also determined the Compensation Ratio (CR) for bivalve shell Ostrea edulis, i.e. how many individuals of $O$. edulis are required to replace the function of one $P$. nobilis in terms of filtration capacity, which is $\mathrm{CR}=2.72 \pm 0.30$ (11.03\%). This paper provides a new approach to the MME of $P$. nobilis indicating urgent need for the marine ecosystem remediation and replacement of the lost ecosystem service by cultivation of compensatory species.

Keywords: Ecosystem service loss, conservation, marine ecology, mass mortality event, Pinna nobilis L. 


\section{INTRODUCTION}

Pinna nobilis (Linnaeus, 1758), a Mediterranean endemic bivalvia, is on the brink of extinction after its populations were ravaged by Mass Mortality Events (MME) caused by microbiological agents in just a few years. The first Mass Mortality Event occurred at multiple locations in the Spanish Mediterranean Sea (SW Mediterranean Sea) separated by hundreds of kilometers (VazquezLuis et al., 2017). This phenomenon has spread to Italy, France, Tunisia, Greece, Cyprus, Albania and Turkey (IUCN 2019; Öndes et al., 2020; Cabanellas-Reboredo, 2019) using surface currents throughout the Mediterranean until the spring of 2021, when the last refuge (disease-free) zone, the Marmara Sea in Turkey, was strucked with a mortality rate of $88 \%$ (Cinar, 2021).

In the Neum Bay $(\mathrm{B} \& \mathrm{H})$, P. nobilis had been mentioned in the inventory of marine fauna 39 years ago (Šoljan, 1980). Recently, one population was identified and georeferenced (Čelebičić et al., 2018) and, subsequently, an underwater survey of 1.4 ha was performed. MME with $100 \%$ mortality was determined, which was concluded to had been occurring over the past three years (Čelebičić et al., 2020), which coincided with the MME in the neighbouring waters of the Republic of Croatia (Šarić, 2020).

Previous findings indicated that the protozoan Haplosporidium pinnae was the main cause of the disease, but all studies up to date indicate that this is a multifactorial disease. It is now known that the microorganisms responsible for the disease are $H$. pinnae, Mycobacterium sp., Vibrio sp., Rhodococcus erythropolis, Rh. qingshengii and Perkinsus sp. (see Scarpa et al., 2020 and reference therein, Scarpa et al., 2021).
The spread of the pathogens is reinforced by the wider deterioration of the coastal marine environment and the effects of climate change. Sea warming is corelated with the increase in frequency and extent of mucilaginous events (Goffredo et Dubinsky, 2014), and these aggregates can act as the carriers of microorganisms, spreading pathogenic bacteria (Danovaro et al., 2009). Increased sea temperature could lead to pathogen outbreaks and intensification of pathogenicity for some species, as it was noted for Vibrio mediterranei infecting $P$. nobilis (Prado et al., 2020). Number of pathogens associated with the $P$. nobilis diseases suggests that the immune status of the animals could be involved (Carella et al., 2020). Also, increase in sea water temperature is correlated with the episodes of mass mortality, both in the Mediterranean (Garrabou et al., 2019) and on a global scale (other species) (Smale et al., 2019), its positive impact on the formation of marine mucilage aggregates, or the transformation of a previous symbiont into a pathogen due to changes in the inner conditions of the host (Darriba, 2017). The global climate changes are recognized to be one of the main drivers for biological changes at any scale.

P. nobilis provides a number of ecosystem services. Firstly, it contributes to water clarity for its filterfeeding activities biofiltrate large amounts of organic matter from suspended detritus, and provide a habitat for a number of species (Basso et al., 2015).

By filtering microalgae and other particles, bivalves can clarify turbid sea water by digesting organic particles and converting the non-digestible particles into quickly settling feces and pseudofeces. They are main factors in controling seton concentration in natural waters. The clearance rate of bivalves is correlated with flow rates, food concentration, and temperature. Clearance rates range between 0.4 
and $6.51 / \mathrm{hr} / \mathrm{g}$ dry weight of bivalve tissue, for P. nobilis $5.99 / \mathrm{hr} / \mathrm{g}$ dry weight (Riva, 2012; See Shpigel M. 2005 and reference therein).

Today, this species is listed on the world IUCN Red List as CE (Critically Endangered), and it has been classified as a species of Community Interest in need of strict protection by the European Habitat Directive (92/43 / EEC) and as an Endangered Species by the Protocol Concerning Specially Protected Areas and Biological Diversity in the Mediterranean from the Barcelona Convention (Annex II).
Given that, in accordance with the IUCN guidelines, scientists are rescuing surviving individuals both by in-situ and ex-situ conservation measures. In general, their conservation approaches are speciesfocused, while this paper points out the ecosystem damages in the Mediterranean caused by the loss of $P$. nobilis populations and their ecosystem service. It is our intention to point out the problem from a slightly different perspective.

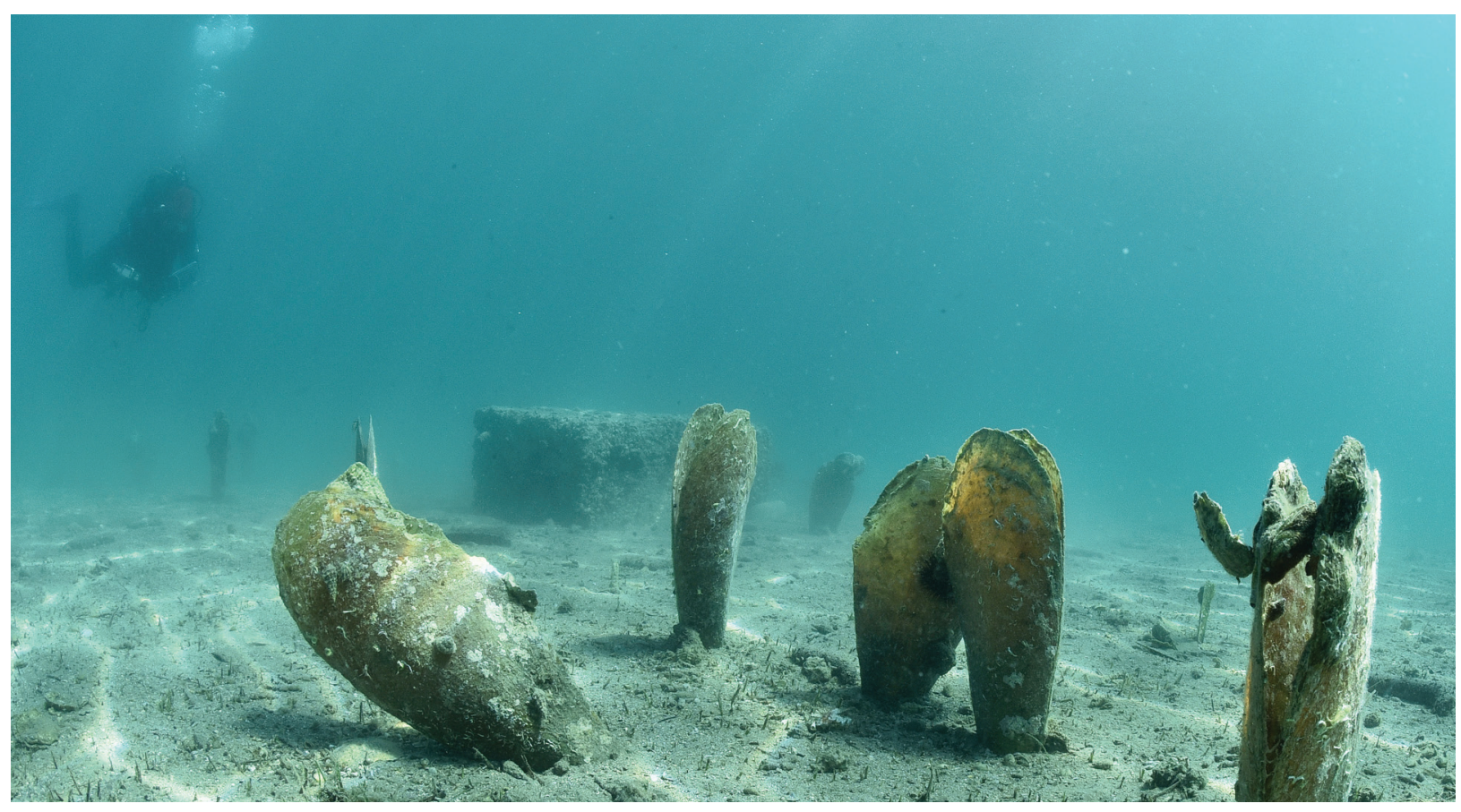

\section{Figure 1}

Dead individuals of Pinna nobilis after MME (Photo by Adnan Drnda) 


\section{MATERIAL AND METHODS}

\section{Study area}

The research was conducted in the area of Neum Bay and the part of Mali Ston Bay that belongs to $\mathrm{B} \& \mathrm{H}$ territorial waters. 10 localities as shown in Figure 2 were selected, and 26 transects $70 \mathrm{~m}$ long and $7 \mathrm{~m}$ wide, i.e. a total area of $420 \mathrm{~m}^{2}$, were searched. The total search area was $10920 \mathrm{~m}^{2} .12$ transects are located in the zone of artificial shores (A) and 14 in the zones of natural shores $(\mathrm{N})$.

\section{Field study methodology}

Each transect is georeferenced with a GARMIN GPSMAP64s. We recorded bottom types for each transect, depth of found individuals, and whether the littoral is of anthropogenic or natural origin (García-March and Vicente, 2006).

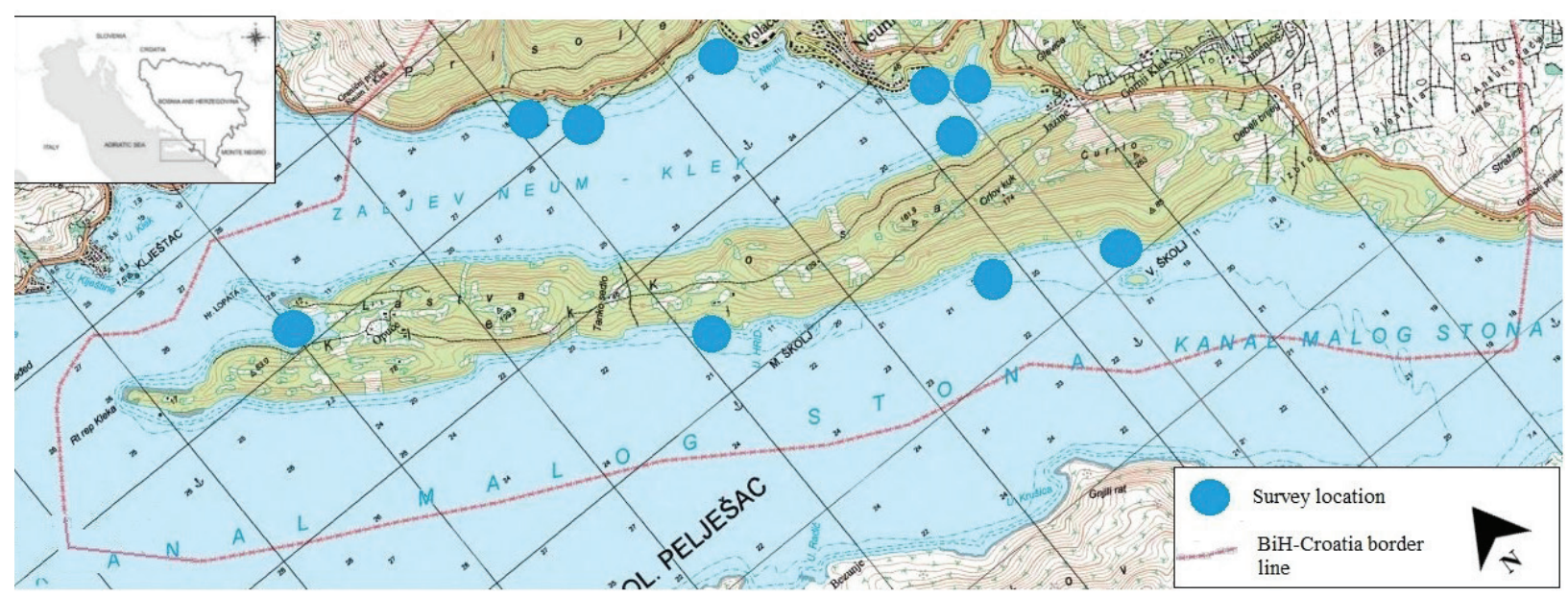

Figure 2

Bosnia and Herzegovina marine teritory with survey locations (Figure by Alija Bojadžić)

Photo material is made using GoPro Hero 7 Black, photo mode, Hugyfot housing, warm white lighting.
Data was recorded using SCUBA slates: maximum width and depth at which individuals were found, and their health condition (García-March and Vicente, 2006; Šarić et al., 2020). 


\section{Data analysis}

We calculated the number of samples needed for 95\% CI with 5\% margin of error and came with the number of 385 individuals needed for population of unknown size.

Population density $\mathrm{P}_{\text {density }}$ (ind $/ 100 \mathrm{~m}^{2}$ ) was determined for each transect separately for two groups of transects, those with artificial anthropogenic embankments (A) and natural (N), and for the total search area (Šiletić and Peharda, 2003).

Based on the results for vertical distribution of individuals, we determined the surface of area of the B\&H sea for the populations of Pinna nobilis L. $\left(\mathrm{P}_{\text {area }}\right)$ using GIS software.

The total number of individuals (TNI) of Pinna nobilis $\mathrm{L}$. population of the $\mathrm{B} \& \mathrm{H}$ sea was estimated $(95 \% \mathrm{CI})$ using formula TNI $=\mathrm{P}_{\text {area }} / \mathrm{P}_{\text {density }}$.

Using the method of Tempesta et al. 2013 for calculating max. shell height, we determined what the age structure of the populations was (Šiletić and Peharda, 2003).

Hypothesis $\mathrm{H}_{0}=($ Population density in A zone $=$ Population density in $\mathrm{N}$ zone) was tested using Man Whitney $U$ test (according to results of Shapiro-Wilk test of normality) performed to determine whether there was a negative impact of human embankments and artificial shores on Pinna nobilis L. populations. We used available data for the average tissue weight of individuals. $\mathrm{M}_{\text {Pinna }}=185.86 \pm 20.97 \mathrm{~g}$ (López-Sanmartín et al 2019). Detailed ecophysiological or bioenergetic studies have not yet been conducted for the species, but a mean filtration rate has been determined $\mathrm{MFR}_{\text {Pinna }}=5.99 \mathrm{~L} \mathrm{~h}^{-1} \mathrm{~g}^{-1}$ in work of Rive et al. 2012.
The total mass of all individuals $\mathrm{MT}=\mathrm{TNI} *$ $\mathrm{M}_{\text {Pinna }}$ was estimated in order to calculate hourly biofiltration rate of the entire population (PFR), that is, hourlyor daily loss to the ecosystem in the biofiltration sense in the absence of this species.

$\mathrm{PFR}=\mathrm{MT} * \mathrm{MFR}_{\text {Pinna }}$

The compensatory value for another species of seashell living in our sea (Ostrea edulis) relative to Pinna nobilis was determined using the available data, and we obtained the compensatory ratio (CR) of how many individuals with average weight can substitute indivudual filtrating rate (IFR) of Pinna nobilis with average weight of tissue mass. These values are furtherly easily extrapolated to the entire population.

$\mathrm{IFR}_{\text {Pinna }}=\mathrm{M}_{\text {Pinna }} * \mathrm{MFR}_{\text {Pinna }}$

$\mathrm{IFR}_{\text {Ostrea }}=\mathrm{M}_{\text {Ostrea }} * \mathrm{MFR}_{\text {Ostrea }}$

(Thorngren et al. 2019; Newell et al. 2005)

$\mathrm{CR}=\mathrm{IFR}_{\text {Pinna }} / \mathrm{IFR}_{\text {Ostrea }}$

\section{RESULTS}

A total of 565 Pinna nobilis L shells were found. The mortality rate was $100 \%$ (95\% CI margin of error $5 \%$ for unknown population size). They were found at depths ranging from 1.6 to 15.7 $\mathrm{m}$. The maximum depth of the found individuals correlates with the depth of occurrence of muddy substrate bottom type (Fig.3).

The smallest total height of the dead individual was $23 \mathrm{~cm}$, which tells us that all individuals were adults (Šiletić and Peharda, 2003). 
Vertical distribution of individuals and bottom types for each transect

Transect (n)

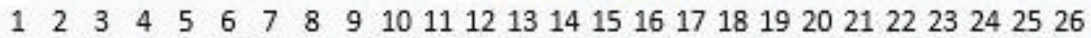
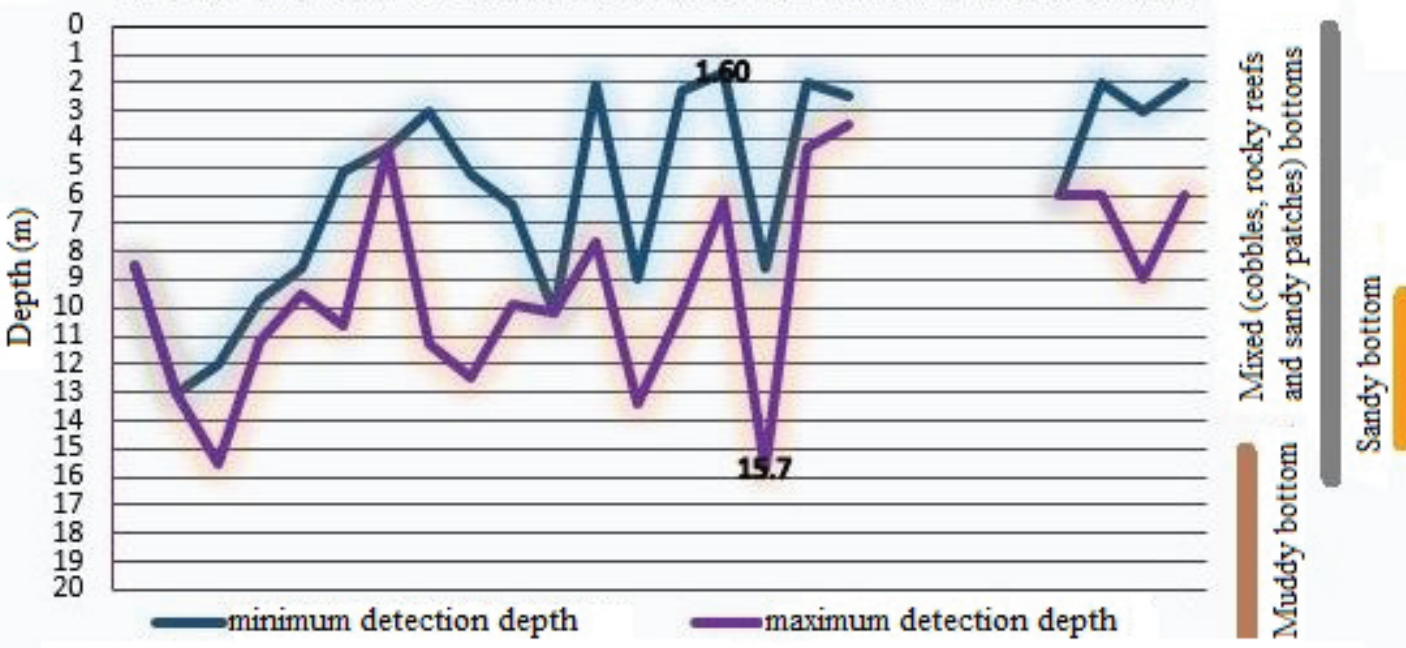

\section{Figure 3}

Field data colected using transects - vertical distribution was important for retrospective determination of spatial distribution

Statistical analysis of data (Mann-Whitney $U$ test) on population densities found the statistically significant difference between the mean population densities in zone A and zone $\mathrm{N}(\mathrm{p}=0.000)$, so we decided to treat the two zones separately in further observations as seen in Table 1 and Figure 4.

Table 1 Consecutive results summary

\begin{tabular}{lccc}
\hline & $\begin{array}{c}\text { Zone A } \\
\text { (artificial) }\end{array}$ & $\begin{array}{c}\text { Zone N } \\
\text { (natural) }\end{array}$ & $\begin{array}{c}\text { Population area } \\
(\mathrm{A}+\mathrm{N})\end{array}$ \\
\hline $\begin{array}{l}\text { Total seabottom surface within } \\
\text { detection depths } \mathrm{m}^{2}\end{array}$ & 195143.23 & 625650.58 & 820793.81 \\
\hline Mean population density(ind/100 $\left.\mathrm{m}^{2}\right)$ & $0.46 \pm 0.34$ & $9.22 \pm 4.35$ & $5.17 \pm 2.84$ \\
\hline Total number of individuals (TNI) & $898 \pm 663$ & $57685 \pm 27216$ & $58583 \pm 27879$ \\
\hline $\begin{array}{l}\text { Total mass of the population (MT) in } \\
\text { tonnes ( })\end{array}$ & $0.18 \pm 0.14$ & $11.29 \pm 6.26$ & $11.47 \pm 6.41$ \\
\hline $\begin{array}{l}\text { Hourly biofiltration rate of } \\
\text { population }(\mathbf{P F R}) \text { in cubic } \\
\text { meters }\left(\mathrm{m}^{3}\right)\end{array}$ & $1082.70 \pm 851.42$ & $45092.93 \pm 14998.97$ & $68722.11 \pm$ \\
\hline
\end{tabular}




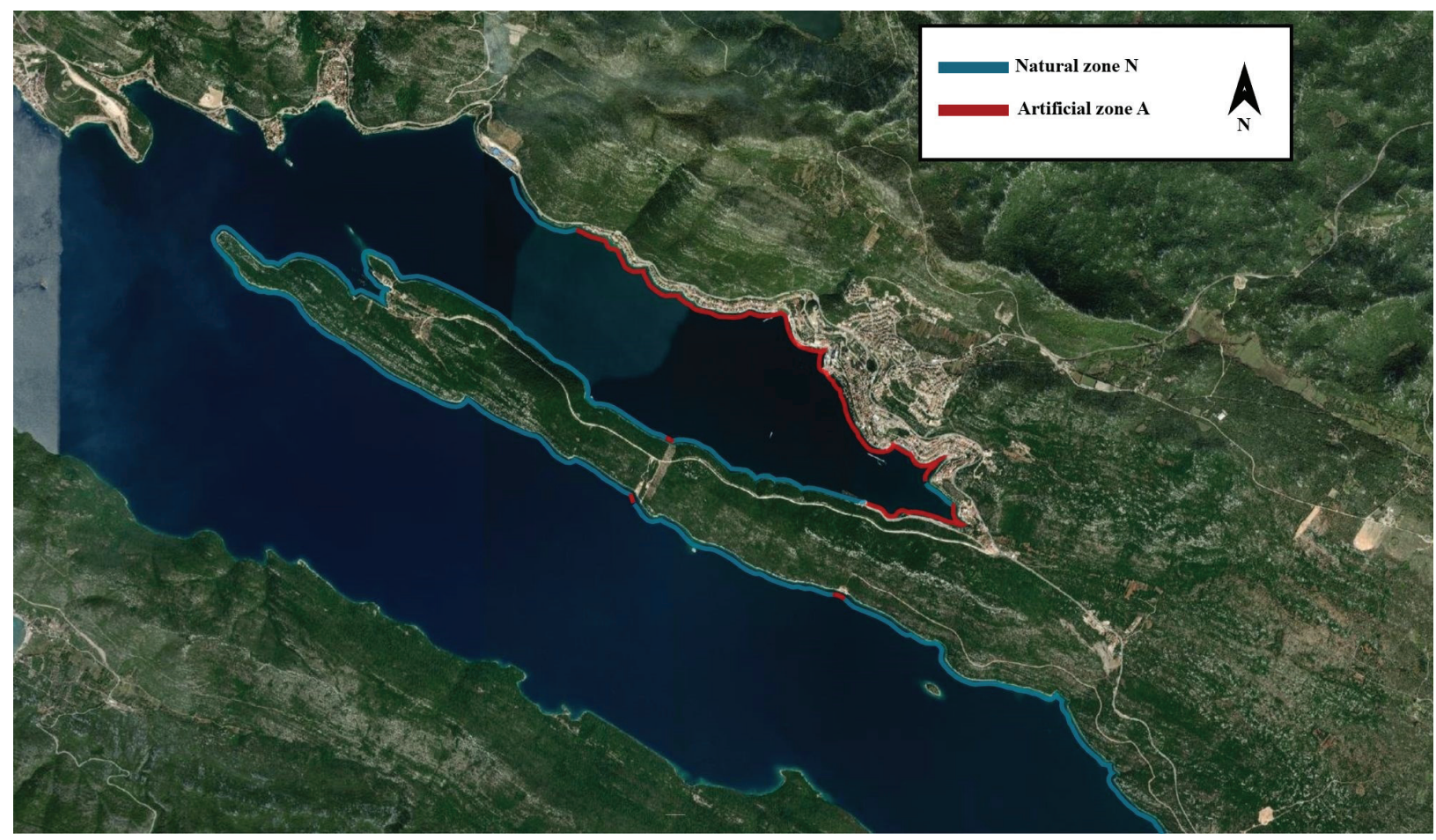

Figure 4

Two zones with significantly different mean population densities (original figure)

If we take into account that the volume of the Neum Bay is $0.2 \mathrm{~km}^{3}$, we can easily estimate how long it took the dead population of Pinna nobilis L. to filter the entire volume of the Neum Bay as shown in Figure 5.

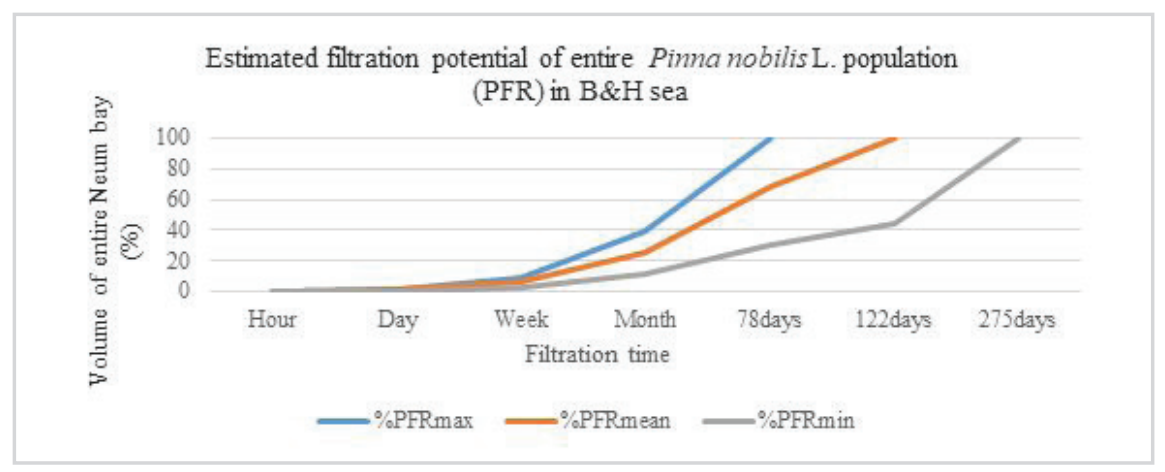

\section{Figure 5}

Quantification

of the species

ecosystem service in

chronological sense

Compensatory ratio for Ostrea edulis is calculated with CI 95\%:

$\mathrm{F}_{\text {indOstrea }}=63 \mathrm{~g} * 6.5 \mathrm{~L} / \mathrm{h}=409.5 \mathrm{~L} / \mathrm{h}$

$\mathrm{F}_{\text {indPinna }}=185.86 \mathrm{~g} \pm 20.97 * 5.99 \mathrm{~L} / \mathrm{h}=1113.3 \pm 125.61 \mathrm{~L} / \mathrm{h}$

$\mathrm{CR}=1113.3 \pm 125.61 \mathrm{~L} \mathrm{~h}^{-1} / 409.5 \mathrm{~L} \mathrm{~h}^{-1}=2.72 \pm 0.30$ 


\section{DISCUSSION AND CONCLUSION}

Based on the situation in the field, area and location of the search and the number of observed individuals, we can confirm with 95\% CI that $100 \%$ Mass Mortality Event of Pinna nobilis L. occurred in Bosnia and Herzegovina, which is in line with previous scientific observations in our sea (Celebicic et al. 2020) and neighboring Croatia, where 100\% MMEs were also recorded. (Saric 2020, Cizmek et al 2020). In neighboring Croatia, parasite Haplosporidium pinnae was identified by histological and molecular methods in all affected sampled individuals, while Mycobacterium sp. and gram negative bacilli were detected in some affected and live bivalves. Unfortunately, as we did not find a single living individual, we could not identify the causes of the disease, and we must assume that they are those found in individuals in Croatia given the specific connection, i.e. the environment of the B\&H sea with the Croatian Sea.

As the B\&H sea is very small, its entire surface belongs to the type of habitat and biocenosis of well-sorted fine sands (Barcelona Convention III. 2.2.) that are part of sandbanks slightly covered by sea water at all times (NATURA 20001110) (Celebicic et al., 2018). It has been under anthropogenic pressure for many years. Now, we see the justification of Recommendations for preserving this type of habitat by, primarily, prohibiting constructions at the coast, especially creating artificial gravel beaches (BakranPetricioli, 2016). Since Pinna nobilis L. is a sessile species that filters about 6 liters of water per hour with a life span that can exceed 45 years (GarcíaMarch et al., 2019), it is an ideal bioindicator of coastal waters quality (Scarpa et al. 2021).

The problem pointed out in the work of Celebicic, 2018 related to the burial of benthos and the populations of Pinna nobilis with building materials and gravel for artificial beaches in the Neum Bay, is still current. Distribution of the populations of Pinna nobilis after this extensive field research and distribution and density of their populations indicated a direct anthropogenic impact on this species to the associated biocenoses and the entire marine ecosystem of B\&H. Given the situation on the ground and the alarming situation with MME, we had to resort to a retrospective method of analyzing the distribution, density and age structure of the populations in order to draw conclusions. We counted upright dead individuals, laid down and fragmented, if they could be approximately reconstructed. In any case, we designed the search so that the data we collected were as accurate as possible.

Mean population density for transects with artificial beaches and banks was $0.46 \pm 0.34$ ind $/ 100 \mathrm{~m}^{2}$, while for transects with natural shores it was $9.22 \pm 4.35$ ind $/ 100 \mathrm{~m}^{2}$. The total population mean density was $5.17 \pm 2.84$ ind $/ 100 \mathrm{~m}^{2}$. We notice similarities with two different groups of data in the works from 1986 to 2020 collected in B\&H, Adriatic Sea and the whole Mediterranean that correspond to our different results for two zones (Combelles et al., 1986; Zavodnik et al., 1991; Celebicic et al., 2018; Celebicic et al. 2020; Cizmek et al., 2020). This aspect should be taken into account in future research on marine ecosystems, especially in research on sessile organisms and their communities.

The vertical distribution was limited to mixed (cobbles, rocky reefs and sandy patches) bottoms and sandy bottoms, while in the zone with depth of over 15.7 meters, where muddy substrate already occurs, there were no fan shell individuals. Two areas were clearly defined, the first one $\left(\mathrm{P}_{\text {area }}\right)$ was present up to 15 meters depth and 50 meters 
horizontally and perpendicularly to the coast. It was inhabited by Pinna nobilis L., while the second stratum extended to the middle of the Neum Bay and Mali Ston Bay without individuals of this species (Figure 6.). We did not notice the presence of a habitat type with the flowering plant Posidonia oceanica meadows. As factors potentially affecting detectability, namely, the size of fan mussel individuals, a habitat type and water visibility were all absent and given the good visibility, absence of juveniles and a habitat type inhabited by Posidonia oceanica meadows, we had no visual obstacles during our underwater surveys (as shown in Figure 7), and we did not specifically address the detection function (Tsatiris et al., 2018).

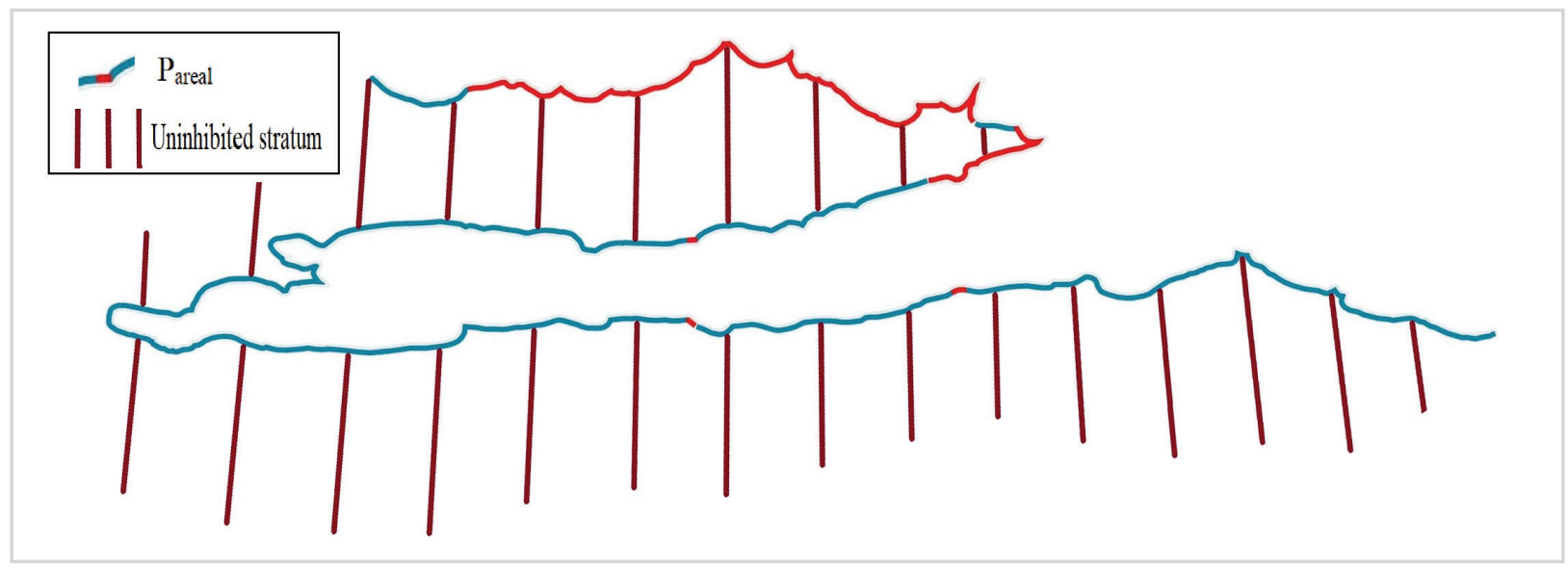

\section{Figure 6}

Pinna nobilis area $\left(\mathrm{P}_{\text {area }}\right)$ and uninhibited part of $\mathrm{B} \& \mathrm{H}$ aquatorium (uninhibited area) (original figure).

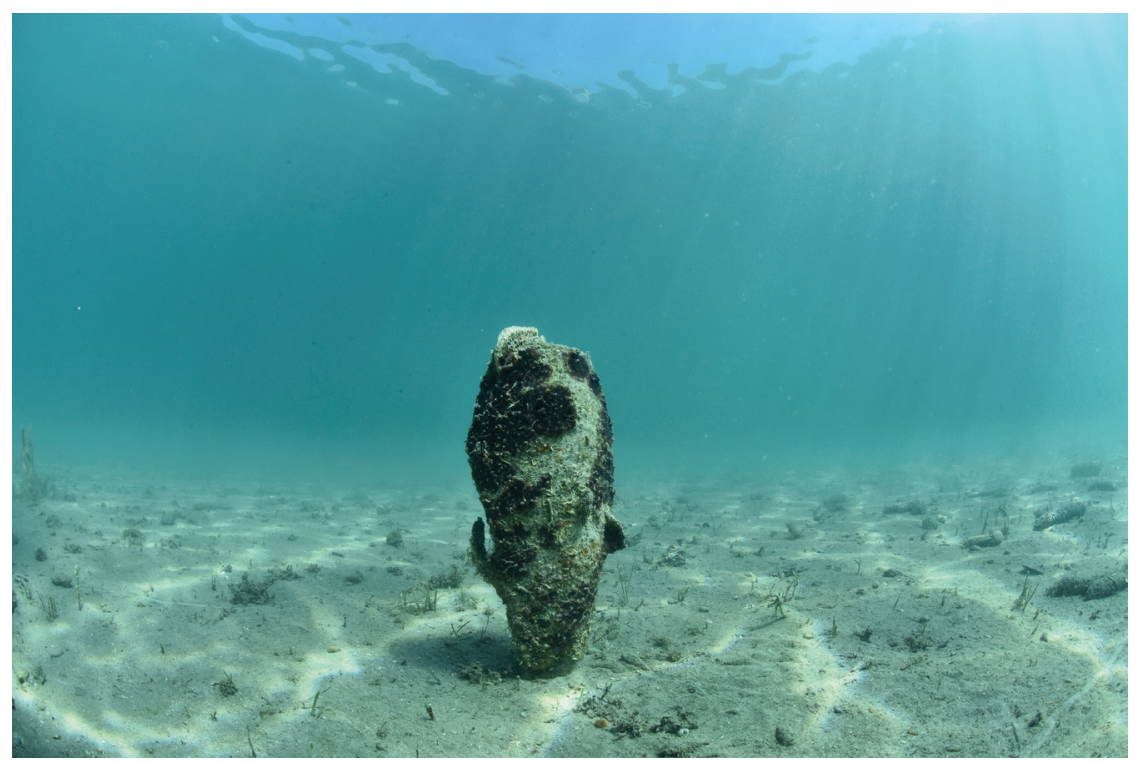

Figure 7

Excellent conditions for underwater surveys (Photo by

Samir Solaković). 
We estimated the TNI- total number of individuals lost and loss of its water filtrating ecosystem service in maintaining clearance and turbidity. We showed a potential method of assessing the loss in terms of biofiltration and a possible tool in future remediation of the Mediterranean marine ecosystems. Based on the obtained data, we calculated that $58583 \pm 27879$ individuals with biomass of $11.47 \mathrm{t} \pm 6.41( \pm 55.87 \%) \quad$ were lost, with the total population hourly filtration potential (PRF) of $68722.11 \pm 38396.86( \pm 55.87 \%)$ 95\% CI. Total population of this species could filter the entire volume of the Neum Bay $\left(0.2 \mathrm{~km}^{3}\right)$ in a period of 78-275 days.

Particulate organic matter, inorganic particles, phytoplankton and larvae of some marine invertebrates are filtered from the water column by fan shells filter feeding and then discharged as biodeposits in the process that clarifies the water column and transfers organic and nutrient-rich particles to the bottom (Dame, 1996; Newell, 2004; Dumbauld et al., 2009). Fan shell populations, together with other filter feeding bivalvia species, can help against developing and sustaining excessive phytoplankton blooms driven by anthropogenic nitrogen introduction. Chlorophyll concentration and turbidity are fundamental indicators of marine ecosystem quality. With the filtration function of suspension feeding bivalves, inorganic particles from the water column and the phytoplankton from suspension are removed and can counteract a negative symptom of eutrophication (Haamer, 1996, Officer et al., 1982, Landry, 2002). Better water clarity allows deeper light penetration, increasing growth of submerged aquatic vegetation (SAV), and vice versa (Everett et al., 1995; Carroll et al., 2008; Wall et al., 2008). Water turbidity affects water temperature, as suspended particles in a water column absorb and scatter sunlight, hence determining the extinction of solar radiation (Paaijmans 2008). With temperatures going up much faster than the global average the sea level rises and the Mediterranean is becoming the fastest-warming and the saltiest sea on our planet. With the loss of this species resulting in the increase of water turbidity, even if only in the shallowed and closed waters, the situation will inevitably worsen . These are just some of the facts and only a part of the bigger picture related to the ecosystem services of this species. We have not dealt with induction of denitrification or sequestration of carbon or many more issues. We should react in time with remediation, that is, attempt to replace this species with another bivalvias that are easily and quickly cultivated and can supstitute its services.

In the end, we hope that the attempts to save Pinna nobilis L. from extinction will succeed, and that we will very soon see our queen of the Mediterranean in old-new habitats, even better and healthier habitats after our timely action. Finally, we conclude that the conservation status of Pinna nobilis L. in Bosnia and Herzegovina is that of Critically Endangered/Extinct (CE/Ex).

\section{ACKNOWLEDGEMENTS}

Field research was funded by Ministry of Civil Affairs of Bosnia and Herzegovina.

Also, thanks for the great commitment during the field research to: Alija Bojadžić, Adnan Drnda, Sanjin Gutić, Midhat Kozadra, Matjaž Majcenović, Davor Mulalić, Mak Mulalić, Samir Solaković and Mirza Tahirović.

\section{CONFLICT OF INTEREST}

The authors declare no conflict of interest. 


\section{REFERENCES}

Bakran-Petricioli T. 2016. Marine habitats-Manual for inventory and monitoring (in Croatian). 2. Izdanje, Izdavač Hrvatska agencija za okoliš i prirodu. Zagreb, Croatia pp. 91-4.

Basso L, Hendriks I, Duarte CM. 2015. Juvenile Pen Shells (Pinna nobilis) Tolerate Acidification but Are Vulnerable to Warming. Estuar Coast, 38 (6), pp. 1976-85. JSTOR, www. jstor.org/stable/45277379. (accessed 15 June 2021).

Basso L, Vázquez-Luis M, García-March JR, Deudero S, Alvarez E, Vicente N, et al. 2015. The Pen Shell, Pinna nobilis: A Review of Population Status and Recommended 409 Research Priorities in the Mediterranean Sea. Adv Mar Biol, 71, 109-60. doi: 10.1016/bs.amb.2015.06.002

Bilkovic D, Mitchell M. 2014. Biofiltration potential of ribbed mussel populations. Virginia Institute of Marine Science, College of William and Mary. doi.org/10.21220/V5ZQ6K

Cabanellas-Reboredo M, Vázquez-Luis M, Mourre B. et al.2019. Tracking a mass mortality outbreak of pen shell Pinna nobilis populations: A collaborative effort of scientists and citizens. Sci Rep, 9, 13355. doi.org/10.1038/s41598-01949808-4

Carella F, Elisabetta A, Simone F, Fulvio S, Daniela M, et al. 2020. In the Wake of the Ongoing Mass Mortality Events: Co-occurrence of Mycobacterium, Haplosporidiumand Other Pathogens in Pinna nobilis Collected in Italy and Spain (Mediterranean Sea). Frontiers in Marine Science, 7, 48. doi. org/10.3389/fmars.2020.00048

Carroll J, Gobler CJ, Peterson BJ. 2008. Resource limitation of eelgrass in New York estuaries: Light limitation and nutrient stress alleviation by hard clams. Mar Ecol Prog Ser, 369, 39-50.

Celebicic M, Katica M, Gradascevic N. 2018. The presence of Pinna nobilis L. in the Gulf of Neum as an argument for reevaluation of its conservation status in Bosnia and Herzegovina. J Black Sea / Mediterranean Envir, 24(2), 157-62.

Cinar M, Bilecenoglu M, Yokeş M, Güçlüsoy H. 2021. The last fortress fell: mass mortality of Pinna nobilis in the Sea of Marmara. Mediterr Mar Sci, 22(3), 669-76. doi.org/10.12681/ mms. 27137

Combelles S, Moreteau J C, Vicente N. 1986. Contribution a la connaissance de l'écologie de Pinna nobilis L. (Mollusque: Eulamellibranche). Sci Rep Port Cros Natl Park, 12, 29-43.

Čižmek H, Čolić B, Gračan R, Grau A, Catanese G. 2020. An emergency situation for pen shells in the Mediterranean: The Adriatic Sea, one of the last Pinna nobilis shelters, is now affected by a mass mortality event, J Invertebrate Pathol, 173, 2020, 107388, doi.org/10.1016/j.jip.2020.107388.

Čelebičić M, Gradaščević N, Viteškić V. 2020. Is Pinna nobilis L. critically endangered in Neum bay, Bosnia and Herzegovina? Veterinaria, 69(3), 221-7.
Dame R F, 1996. Ecology of Marine Bivalves: An Ecosystem Approach. CRC Press, Boca Raton, Florida.

Danovaro R, Fonda Umani S, Pusceddu A. 2009. Climate Change and the Potential Spreading of Marine Mucilage and Microbial Pathogens in the Mediterranean Sea. PLoS ONE, 4 (9), e7006.

Darriba S. 2017. First haplosporidan parasite reported infecting a member of the Superfamily Pinnoidea (Pinna nobilis) during a mortality event in Alicante (Spain, Western Mediterranean). J Invert Pathol, 148, 14-9. doi: 10.1016/j.jip.2017.05.006

Dumbauld BR, Ruesink JL, Rumrill SS . 2009. The ecological role of bivalve shellfish aquaculture in the estuarine environment: A review with application to oyster and clam culture in west coast (USA) estuaries. Aquaculture, 290(3-4), 196-223.

EEC. 1992. Council directive 92/43/EEC of 21 May 1992 on the conservation of natural habitats and of wild fauna and flora. Offic J Eur Comm, L206, 43.

Everett RA, Ruiz GM, Carlton JT. 1995. Effect of oyster mariculture on submerged aquatic vegetation: An experimental test in a Pacific Northwest estuary. Mar Ecol Prog Ser, 125, 205-17.

Garcia-March JR, Vicente N. 2006. Protocol to study and monitor Pinna nobilis populations within marine protected areas. Malta Environment and Planning Authority, Med PAN Project. pp. 17-38.

Garrabou J, Gómez-Gras D, Ledoux JB, Linares C, Bensoussan N, et al. 2019. Collaborative database to track mass mortality events in the Mediterranean Sea. Front Mar Sci, 6, 707. doi: 10.3389/fmars.2019.00707

Goffredo S, Dubinsky Z. 2014. The Mediterranean Sea: its History and Present Challenges. Springer, Dordrecht, 678 pp.

Haamer, J. 1996. Improving water quality in a eutrophied fjord system with mussel farming. AMBIO, 25(5), 356-62.

IUCN. 2019. Red List of Threatened Species: Pinna nobilis. (updated 18 November 2021; cited 20 November 2021) Available from: https://www.iucnredlist.org/ species/160075998/160081499.

J.R. García-March, S. Hernandis, Vázquez-Luis M, Prado P, Deudero S, Vicente N, et al. 2019. Age and growth of the endangered fan mussel Pinna nobilis in the western Mediterranean Sea, Marine Envir Res, 153, 2020, 104795 , doi.org/10.1016/j.marenvres.2019.104795.

Landry T. 2002. The potential role of bivalve shellfish in mitigating negative impacts of land use on estuaries. In: Effects of Land Use Practices on Fish, Shellfish, and Their Habitats on Prince Edward Island, Canadian Technical Report of Fisheries and Aquatic Sciences, (ed. Cairns DK), Prince Edward Island, Canada.

López-Sanmartín M, Catanese G, Grau A, Valencia JM, García-March JR, Navas JI. 2019. Real-Time PCR based test 
for the early diagnosis of Haplosporidium pinnae affecting fan mussel Pinna nobilis. Plos One, 14(2), e0212028. doi. org/10.1371/journal.pone.0212028

Newell R I E, Koch E W. 2004. Modeling seagrass density and distribution in response to changes to turbidity stemming from bivalve filtration and seagrass sediment stabilization. Estuaries, 27(5), 793-806.

Newell RIE, Fisher TR, Holyoke RR, Cornwell JC. 2005. Influence of eastern oysters on nitrogen and phosphorus regeneration in Chesapeake Bay, USA. In: Dame RF, Olenin $\mathrm{S}$. (Eds), The comparative roles of suspension feeders in ecosystems, NATO ASI Sci Ser 4 Earth Environ Sci, SpringerVerlag, Berlin, pp. 93-120.

Officer C B, Smayda T J,Mann R. 1982. Benthic filter feeding: A natural eutrophication control. Marine Ecol Prog, Ser 9, 203-10.

Öndes F, Ulan V, Akçalı B, Güçlüsoy H. 2020. Mass mortality of the fan mussel, Pinna nobilis in Turkey (eastern Mass mortality of the fan mussel, Pinna nobilis in Turkey (eastern Mediterranean). Marine Ecology, 41(5), e 12607. doi: 10.1111/maec.12607

Paaijmans, K.P., Takken, W., Githeko, A.K. et al. 2008. The effect of water turbidity on the near-surface water temperature of larval habitats of the malaria mosquito Anopheles gambiae . Int J Biometeorol 52, 747-53. doi.org/10.1007/ s00484-008-0167-2

Prado P, Carrasco N, Catanese G, Grau A, Cabanes P, Carella F, et al. 2020. Presence of Vibrio mediterranei associated to major mortality in stabled individuals of Pinna nobilis L. Aquaculture, 519, 734899. doi: 10.3389/conf. fmars.2019.08.00142

Riva A. 2002. Methodological approach of some bioenergetics parameters on Pinna nobilis. In: IOPR Premier Séminaire International sur la Grande Nacre de Méditerranée: Pinna nobilis (ed.Vicente N). Nice: Mémoires de l'Institut Océanographique Paul Ricard, pp. 91-102.

Scarpa F, Sanna D, Azzena I, Cossu P, Casu M. 2021. From dark to light andback again: is Pinna nobilis, the largest Mediterranean shellfish, on the brinkof extinction? Veterinaria 70, 1-14. doi.org/10.51607/22331360.2021.70.1.1.4.

Scarpa F, Sanna D, Azzena I, et al. 2021. Draft Genome Sequence of Rhodococcus qingshengii Strain PN_19, Isolated from a Moribund Individual of Pinna nobilis in Sardinia, Italy. Microbiol Resour Announc.10(23), e0035621. doi:10.1128/MRA.00356-21

Shpigel M. 2005. Bivalves as Biofilters and Valuable Byproducts in Land-Based Aquaculture Systems. In: (Eds. Dame RF, Olenin S.), The Comparative Roles of SuspensionFeeders in Ecosystems. NATO Sci S IV Ear En, 47. Springer, Dordrecht. doi.org/10.1007/1-4020-3030-4_11
Smale DA, Wernberg T, Oliver ECJ, Thomsen M, Harvey BP, Straub SC, et al.. 2019. Marine heatwaves threaten global biodiversity and the provision of ecosystem services. Nat Clim Change, 9, 306-12.

Šarić T, Župan I, Aceto S, Villari G, Palić D, De Vico G, et al. 2020. Epidemiology of Noble Pen Shell (Pinna nobilis L. 1758) Mass Mortality Events in Adriatic Sea Is Characterised with Rapid Spreading and Acute Disease Progression. Pathogens, 9, 776. doi: 10.3390/pathogens9100776

Šiletić T, Peharda M. 2003. Population study of the fan shell Pinna nobilis L. in Malo and Veliko Jezero of the Mljet National Park (Adriatic Sea). Sci Mar, 67, 91-8.

Šoljan T. 1980. Marine fauna of Bosnia and Herzegovina. (in Bosnian). Posebna izdanja, knjiga XLVII, Odjeljenje Prirodnih i matematičkih nauka, knjiga 8. Savjetovanje Problemi inventarizacije životinjskog svijeta $\mathrm{BiH}$ - stanje i perspektive, pp. 21-32.

Tempesta M, Del Piero D, Ciriaco S. 2013. Definition of a new formula for the calculation of the total height of the fan shell Pinna nobilis in the Miramare marine protected area (Trieste, Italy). Ann Ser Hist Nat, 23, 17-22.

Thorngren L, Bergström P, Holthuis TD, Lindegarth M. 2019. Assessment of the population of Ostrea edulis in Sweden: A marginal population of significance? Ecol Evol, 9 (24), 13877-88. doi: 10.1002/ece3.5824

Tsatiris A, Papadopoulos V, Makri D, Topouzelis K, Manoutsoglou E, Hasiotis T, et al. 2018. Spatial distribution, abundance and habitat use of the endemic Mediterranean fan mussel Pinna nobilis in Gera Gulf, Lesvos (Greece): comparison of design-based and model-based approaches. Mediterranean Marine Sci, 19(3), 642-55. doi. org/10.12681/mms.14156

UNEP/MAP-SPA/RAC. 2018. SAP/ RAC: SPA-BD Protocol - Annex II: List of endangered or threatened species.(updated 2021 October 8; cited 2021 October 20). Available from: https://www.rac-pa.org/sites/default/files/annex/annex_2_ en_20182.pdf

Vázquez-Luis M, Álvarez E, Barrajón A, García-March JR, Grau A, Hendriks IE, et al. 2017. S.O.S. Pinna nobilis: A Mass Mortality Event in Western Mediterranean Sea Front Mar Sci, 4, 220. doi: 10.3389/fmars.2017.00220

Wall CC, Peterson BJ, Gobler CJ. 2008. Facilitation of seagrass Zostera marina productivity by suspension-feeding bivalves. Mar Ecol Prog Ser, 357, 165-74.

Zavodnik D, Hrs-Brenko M, Legac M. 1991. Synopsis on the fan shell Pinna nobilis L. in the eastern Adriatic Sea. In: Les Espèces Marines à Protéger en Méditerranée. (eds., Mar Ecol Prog Ser Boudouresque Mar Ecol Prog Ser, Avon M, Gravez V), Gis Posidonie Publ. Marseille, pp. 169-78. 


\section{NAKON POJAVE MASOVNOG UGIBANJA PINNA NOBILIS L. U BOSNI I HERCEGOVINI - PRIJEDLOG ZA REMEDIJACIJU SERVISA BIOFILTRACIJE U POMORSKOM EKOSISTEMU}

\section{SAŽETAK}

Pojava masovnog ugibanja (MME) endemskog školjkaša Pinna nobilis je zabilježen u Mediteranskom moru što je ovu vrstu dovelo na rub izumiranja. Za sada se smatra da je etiologija bolesti multifaktorijelna. Pored širokog spektra patogenih mikroorganizama kao ključnog faktora, neizravnu ulogu igraju i klimatske promjene, npr. porast temperature mora što povećava osjetljivost P. nobilis na patogene. Što se tiče mjera konzervacije, IUCN smjernice preporučuju in situ i ex situ konzervaciju. U našem istraživanju smo istražili $10,920 \mathrm{~m}^{2}$ morskog dna u teritorijalnim vodama Bosne i Hercegovine, pri čemu smo potvrdili prisustvo MME sa mortalitetom od $100 \%$. Na osnovu procjene ukupnog broja jedinki (TNI), procijenili smo kapacitet filtracije ove vrste tj. njenog ekosistemskog servisa u regulaciji vidljivosti i zamućenosti vode u BiH moru. Ovdje prikazujemo potencijalni metod za procjenu oštećenja ekosistema uzrokovanih gubitkom periske i njene usluge biofiltracije morske vode. Naši rezultati su pokazali da je izgubljeno $58583 \pm 27879$ jedinki, što odgovara biomasi od $11.47 \mathrm{t} \pm 6.41 \mathrm{t}( \pm 55.87 \%)$. Potencijal satne filtracije (PRF) $P$. nobilis iznosi $68722.11 \pm 38396.86( \pm 55.87 \%) 95 \% \mathrm{CI}$, što znači da bi populacija ove vrste mogla filtrirati svu morsku vodu Neumskog zaljeva $\left(0.2 \mathrm{~km}^{3}\right)$ u periodu od 78 do 275 dana. Također smo odredili kompenzacijski omjer (CR) za školjku Ostrea edulis, odnosno, koliko je jedinki $O$. edulis potrebno da bi se zamijenila funkcija jedne $P$. nobilis u smislu kapaciteta filtracije čiji je $\mathrm{CR}=2.72 \pm 0.30(11.03 \%)$. Ovaj papir predočava novi pristup MME $P$. nobilis ukazujući na urgentnu potrebu za sanacijom pomorskog ekosistema i zamjenu izgubljenih usluga ekosistema kultivacijom kompenzatornih vrsta.

Ključne riječi: Gubitak ekosistemskih servisa, konzervacija, Pinna nobilis L, pomorska ekologija, slučaj masovnog ugibanja 